\title{
Determinants of Overweight Among Primary School Children in Arba Minch Town, Southern Ethiopia, 202I
}

\author{
Elias Ezol \\ Biruk Gashawbeza ${ }^{1,2}$ \\ 'Department of Comprehensive Nursing, \\ College of Medicine and Health Sciences, \\ Wachemo University, Hosanna, Ethiopia; \\ ${ }^{2}$ Department of Public Health, Paramed \\ College, Arba Minch, Ethiopia
}

Background: The condition of being overweight is the abnormal excessive accumulation of fat in the body. Globally, it is a serious public health issue in both developing and developed countries. Objective: This study aims to identify determinants of overweight among primary school children in Arba Minch town, Southern Ethiopia, 2021.

Methods: A school-based unmatched case control study was conducted from June 20 to 30 , 2021. The total sample size was 285 (95 cases and 190 controls). Multistage sampling technique was used. Data were entered using Epi data 3.1 version and analyzed using SPSS version 24 software. Frequency, tables and figures were used. Bivariable analysis was done and variables with $\mathrm{p}<0.025$ were entered to multivariable logistic regression analysis. Statistical significance was declared at $\mathrm{p}<0.05$ with $95 \%$ confidence interval (CI). Results: The odds of overweight increased 19.8 times more in children whose fathers work in private business [AOR: $19.82,95 \%$ CI: $6.21,63.25$ ], increased 4.8 times more in children who consume meat on more than 2 days per week [AOR: 4.75, 95\% CI: 1.61, 14.03], increased 5 times more in children who consume milk on more than 2 days per week [AOR: 5.02, 95\% CI: 1.80, 13.98], increased 11.9 times more in children who spend more than 6 hours sitting per day [AOR: $11.89,95 \%$ CI: 4.13, 34.28]. And also, odds decreased by $84 \%$ in children who consume fruit on more than 2 days per week [AOR: 0.07, 95\% CI: 0.03 , 0.19 ], decreased $93 \%$ in children who consume vegetables on more than 2 days per week [AOR: $0.16,95 \%$ CI: $0.06,0.42$ ], decreased $67 \%$ in children who consume cereals on more than 2 days per week [AOR: 0.33, 95\% CI: 0.13, 0.84].

Conclusion: Fathers working in private business, consuming fruit, vegetables, cereals, meat and milk on more than 2 days per week and sitting for more than 6 hours per day were determinants for overweight in this study. Therefore, it is better to include fruit, vegetables and cereals in dietary habits, decrease consumption of meat and milk and minimize sitting to less than 6 hours per day including school learning time.

Keywords: overweight, children, elementary school

\section{Background}

The condition of being overweight is an excessive accumulation of fat that impairs or hinders the normal health of the body. ${ }^{1,2}$ Overweight is a chronic condition that is the result of an energy imbalance over a period of time. ${ }^{3}$ The primary source for an energy imbalance is when the number of calories consumed becomes unequal to the number of calories used by the body. ${ }^{1,2,4}$ The cause for this energy imbalance is a combination of several different factors and it varies from individual to individual. $^{1-3}$
Correspondence: Elias Ezo

Email eliasezo805@gmail.com 
The health and well-being of children have a major impact on the overall social and economic health of a nation as today's children are tomorrow's workforce, parents and leaders in various sectors. But, for many years, their nutrition-related health problems have been neglected. However, children's problems with being overweight have a strong tendency to track in to adulthood and become a foundation for substantial increase in the risk of premature development of chronic disease and certain cancers which will have far-reaching impact on the overall welfare and disease burden of a nation. ${ }^{4,5}$ Currently, overweight with obesity is the fifth leading risk for global deaths. ${ }^{1,6}$ Childhood is the key developmental period for early identification and prevention of excessive adiposity of fat in the body that can rise in adulthood. Therefore, the fundamental step in the prevention of overweight is the identification of factors contributing to the rapid increase of overweight among children, and working on it.

Childhood overweight is one of the most serious public health challenges of the 21 st century and its prevalence is increasing in both developing and developed countries. ${ }^{1,4} \mathrm{Up}$ to the 1980 s, developing countries had the lowest rates, but since then the prevalence of overweight has gradually increased in children, especially in those who live urban areas. ${ }^{1}$

In Africa, the number of overweight children has nearly doubled from 5.4 million in 1990 to 10.3 million in $2014 .^{7}$ The occurrence of childhood and adolescent overweight may be unconsidered in African settings, but absolutely, there are more numbers of overweight children living in low and middle income countries including Ethiopia, compared with high income countries. ${ }^{8,9}$

Studies conducted in different parts of Ethiopia show that the prevalence of overweight is increasing over time. It was $9.9 \%$ in Addis Ababa, Ethiopia, ${ }^{10} 14.7 \%$ in Dire Dawa town, Ethiopia, ${ }^{11}$ and $9.1 \%$ in Gondar, Amhara Regional State, Ethiopia. ${ }^{12}$ These findings show that overweight is becoming a health problem of Ethiopia. Dietary habits are changing whenever incomes are rising in the developing countries, with a marked shift from fruit and vegetables to meat, fats and sugar content meals. ${ }^{7}$

In Ethiopia, which is a low-income country that is still suffering from childhood malnutrition, childhood overweight is not yet perceived and considered as an emerging health issue and receives little attention. According to the 2017 annual report of United Nations International Children's Emergency Fund (UNICEF), there is an overall increment of the prevalence of overweight among children from $1.7 \%$ to $3.6 \% .{ }^{6}$ Nevertheless, the efforts do not target children and adolescents in particular. The nation program of Ethiopia, from 2016 to 2020 suggested timely interventions to prevent non-communicable diseases or reduce their severity and consequences, ${ }^{13}$ but did not consider childhood overweight. Information regarding nutritional status of children in Ethiopia is not well documented. ${ }^{14}$

In the study area, there was no information regarding the determinants of child overweight among primary school children, although this stage is a crucial time during which eating and physical activity habits are becoming established. Therefore, this study identified the determinant factors of overweight among primary school children in Arba Minch town, Southern Ethiopia.

\section{Methods and Materials Study Area and Period}

The study was conducted in Arba Minch town, Gamo zone, Southern Nation, Nationalities and Peoples Regional State. It is located at a distance of $454 \mathrm{~km}$ to the south of Addis Ababa, the capital of Ethiopia. Based on the 2007 census data, the population was 74,879. According to the 2020/2021 Arba Minch town education office statistics, the town has 8 governmental and 11 private primary schools. There were 6524 students learning from 5 th to 8 th grade in both governmental and private schools. Regarding the coverage of health facilities, the town has one general and one primary hospital, one health center, private clinics and 25 drug stores. There are five health posts in which health extension workers are working. The study was conducted from June 20 to 30, 2021.

\section{Study Design}

A school-based unmatched case control study was conducted.

\section{Source Population}

All 5th-8th grade students aged 11-15 years in both private and governmental primary schools in Arba Minch town.

\section{Study Population}

Selected 5th-8th grade students aged 11-15 years in both private and governmental primary schools in Arba Minch town.

Case definition: All 5th-8th grade students aged 11-15 years in selected schools who had BMI for age greater than or equal to 85 th percentile. 
Control definition: All 5th-8th grade students aged 1115 years in selected schools who had MBI for age between 5th and 85th percentile.

\section{Inclusion Criteria}

Grades 5th to 8th regular students aged 11-15 years of selected schools in Minch town.

\section{Exclusion Criteria}

Students having edema

Students with body deformity such as kyphosis and scoliosis.

Students who lived less than 6 months in the town.

Underweight (BMI for age less than 5th percentile).

\section{Sample Size Determination}

Sample size was determined using Epi Info 7 version by considering assumptions of $95 \%$ confidence level, power $80 \%$, ratio of control to cases three to one $(3: 1)$, percent of control exposed and adjusted odds ratio from previous unmatched case control study. ${ }^{15}$ Non-response rate $5 \%$ and design effect of 1.5 were considered. Finally, the maximum sample size determined was 285 (95 cases and 190 controls) (Table 1).

\section{Sampling Procedure}

Multistage sampling technique was used. Stratified sampling technique was used to select governmental and private schools. Next, simple random sampling technique was used to select three schools from 11 private and two schools from eight governmental primary schools. Then, proportional allocation was used to select the number of students from government and primary schools. A survey was performed to identify cases one week prior to data collection and 168 cases were identified in selected primary schools. Finally, a lottery method was used to select students by considering the identification number of students as sampling frame and the parents of those selected students were included (Figure 1).

\section{Study Variables \\ Dependent Variable}

Overweight.

\section{Independent Variables}

Socio-demographic characteristics: religion, ethnicity, parent educational level, parental occupation, number of people live in the house, age of child, sex of child, type of school, grade level of child.

Dietary habits characteristics: individual dietary diversity score (fruit, vegetables, cereals, meat, eggs, milk, number of meals per day, food in addition to regular meals, servings of soft drinks, way of getting lunch, eating while watching TV and reading, missing meal habit, taking anti-psychiatric medication).

Physical activities characteristics: working activities, vigorous activities, walk/using bicycle, vigorous intensity sport.

Sedentary behaviors characteristics: way of spending free time, sitting, sleeping habit, familial chronic disease.

\section{Nutritional Knowledge of Children Operational and Term Definition}

Case: BMI for age greater than or equal to 85th percentile. ${ }^{16,17}$

Control: BMI for age between 5th and 85th percentile. $^{16,17}$

Elementary school: school having students learning from grade 5 to grade 8 .

Children: population that exist in the age group between 11 to 15 years. ${ }^{18}$

Vigorous exercise: running or jogging, high intensity aerobic classes, competitive, field sports (soccer) or basketball. ${ }^{19,20}$

Table I Sample Size Determination on Epi-Info Software Among Primary School Children in Arba Minch Town, Southern Ethiopia, 2021

\begin{tabular}{|l|l|l|l|l|l|l|l|}
\hline Variables & $\begin{array}{l}\text { \% of Controls } \\
\text { Exposed }\end{array}$ & AOR & Ratio & $\begin{array}{l}\text { Sample } \\
\text { Size }\end{array}$ & $\begin{array}{l}\text { Non Response } \\
\text { Rate }\end{array}$ & $\begin{array}{l}\text { Design } \\
\text { Effect }\end{array}$ & $\begin{array}{l}\text { Total Sample } \\
\text { Size }\end{array}$ \\
\hline Age & $5.1 \%$ & 6.3 & $3: 1$ & 139 & $5 \%$ & 1.5 & 219 \\
Gender & $61.9 \%$ & 3.5 & $3: 1$ & 181 & $5 \%$ & 1.5 & 285 \\
Physical activity & $28.1 \%$ & 4.6 & $3: 1$ & 90 & $5 \%$ & 1.5 & 144 \\
\hline
\end{tabular}

Abbreviation: AOR, adjusted odds ratio. 


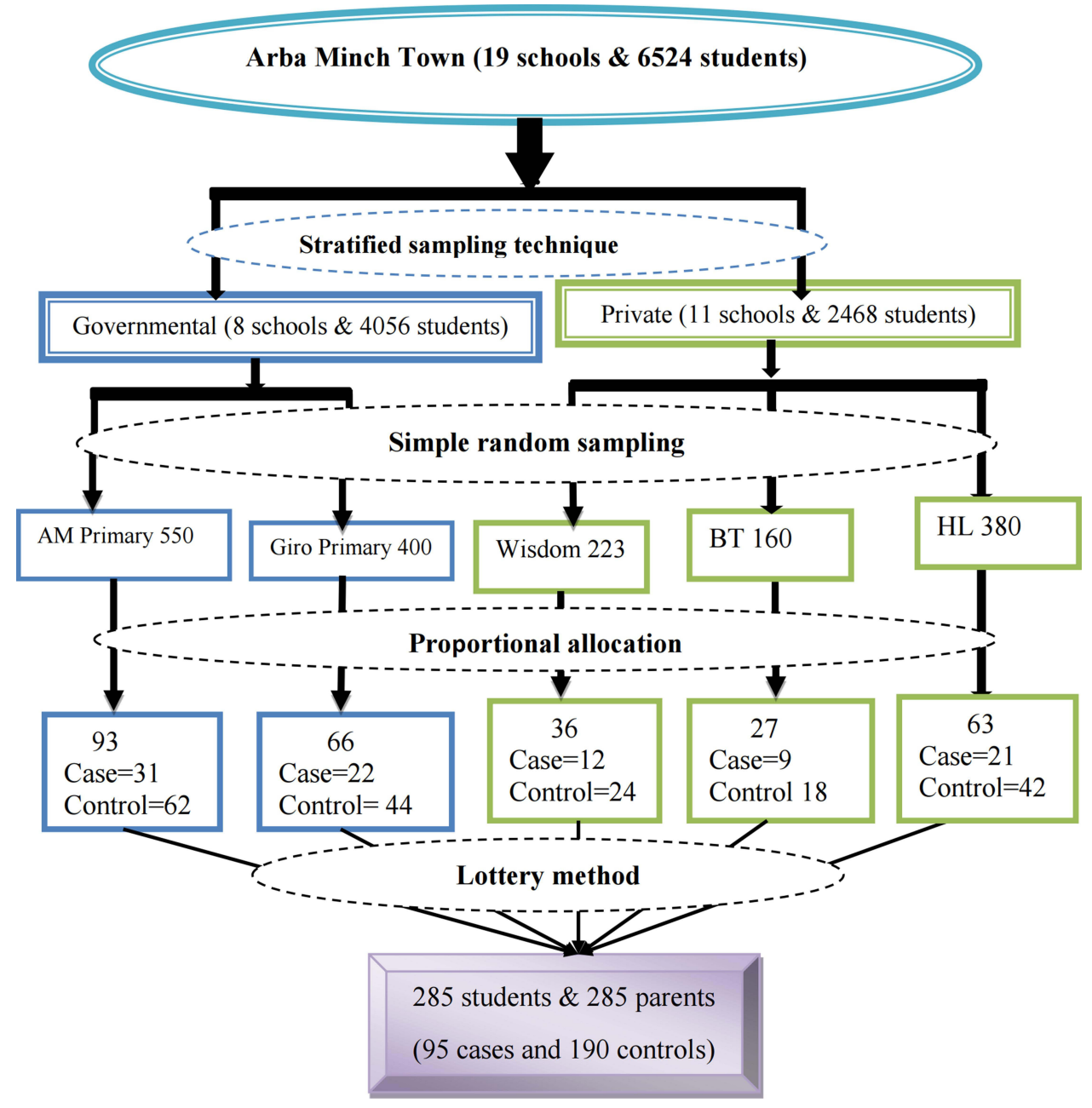

Figure I Schematic presentation of the sampling procedure for primary school children in Arba Minch town, Southern Ethiopia, 202I. Abbreviations: AM, Arba Minch; BT, Birhan Tena; HL, Hibiret Lelimat.

Sedentary behaviors: Time spent using reading books, and/or watching TV, and/or video playing on computer games more than $2 \mathrm{~h} /$ day or sleeping for less than $8 \mathrm{~h}$.

Soft drinks: Frequency of drinking sweetened beverages such as Miranda, Coca-Cola, Fanta and others more than once per day. ${ }^{21}$

Dietary habit: Dietary habit refers to the number of days in which the participant consumed a particular food group (fruits, vegetables, cereals, meat, milk) in weeks in the past months at the time of data collection.

Nutritional knowledge of the children: Assessed using six questions that ask about nutrition related to overweight and then categorized as high if the child scored mean and above or low if the child scored below mean. ${ }^{18}$

Anthropometric measurements: Measurement of weight and height was performed by using calibrated equipment and standardized technique. ${ }^{18}$
BMI: the ratio of weight in kilogram to height in meter square. $^{22}$

\section{Data Collection Tool and Procedure}

The tool contained semi-structured questionnaires. Data were collected by face to face interview using the questionnaire adapted from step-wise chronic disease, Food and Agriculture Organization and other literature ${ }^{22,23}$ and taking anthropometric measurements of weight and height. Data were collected among selected cases and controls randomly. The participants were classified as case and control depending on their percentile status.

\section{Data Quality Control}

Pre-test was carried out on 5\% of the total sample size at one selected primary school (Lante primary school) and the questionnaire was amended accordingly. Five data 
collectors (nurses) and two supervisors (experienced public health officers) were recruited. Training was given for data collectors and supervisors about handling respondents' rights and confidentiality, informed consent and technique of interview. The questionnaire was translated from English to Amharic (the local language of Ethiopia) before data collection and back to English after data collection by a language expert to assure consistency.

The weight scale was calibrated to zero with no object on it and placed on a level surface before measurements were carried out, and children were measured with light clothes and barefoot. The cases and controls were classified by supervisors during data collection and data collectors were blinded to cases and controls. The supervisors reviewed every questionnaire for completeness and consistency. Data collectors submitted the collected data daily to supervisors and investigators. Each questionnaire was checked on a daily basis before data entry for completeness and consistency.

\section{Data Processing and Analysis}

The collected data were entered into Epi data version 3.1 and exported to SPSS version 24 for analysis. Tables, percent and graphs were used to describe results. Binary logistic regression model was used to identify the association between each independent and dependent variable by considering odds ratio with $95 \%$ CI. Statistical significance was considered and all variables with $p<0.025$ in bivariable were entered into multivariable analysis. Model fitness test was done by using Hosmer-Lemeshow model goodness of fit test. Multi colinearity of the independent variables was checked by standard error and variables with standard error $>2$ were dropped from the multivariable analysis. Adjusted odds ratio with $95 \%$ CI was considered to identify the associated factors (determinants of overweight). Finally, statistical significance was declared at $\mathrm{p}<0.05$.

\section{Result}

\section{Socio-Demographic Characteristics of Parents}

A total of 285 (95 cases and 190 controls) children with either parents were interviewed that made the overall response rate $100 \%$. About 88 (46.3\%) controls and 41 (43.2\%) cases of the parents were followers of Orthodox religion. More than half, $114(60.0 \%)$ controls and $51(53.7 \%)$ cases were an ethnic group of Gamo. The educational level of 139 (73.2\%) controls and 47 (49.5\%) cases of fathers was from grade 9-12 and above grade 12 respectively. More than half, 117 (61.6\%) controls and $56(58.9 \%)$ cases of mothers completed grade 9-12. Regarding the occupation of fathers, 90 (47.4\%) controls and $52(54.7 \%)$ cases was merchant and private business, respectively. For mothers, 89 (46.8\%) controls and 41 (43.2\%) cases was merchant and private business, respectively (Table 2).

\section{Socio-Demographic Characteristics of Children}

More than half, 115 (60.5\%) of the controls were females and $69(72.6 \%)$ of cases were males. The mean age of controls was 13.6 with $\mathrm{SD} \pm 1.461$ and the mean age of cases was 12.84 with $\mathrm{SD} \pm 1.331$. More than half, 106 $(55.8 \%)$ of the controls and $53(55.8 \%)$ of cases were learning in government school. About $60(31.6 \%)$ of controls were in 5th grade and $42(44.2 \%)$ of cases were in 6th grade (Table 3).

\section{Eating Habits and Food Preference of the Primary School Children}

The overall eating habits and food preference of the children were explained by categorizing in a reasonable groups for both controls and cases (Table 4).

\section{Physical Activities of the Primary School Children}

The results for physical activity of the children were explained by categorizing in groups for both controls and cases (Table 5).

\section{Sedentary Behavior of the Primary School Children}

The overall results for sedentary behavior of the children were explained in each group for both controls and cases (Table 6).

\section{Nutritional Knowledge of the Primary School Children}

Regarding the nutritional knowledge, 104 (54.7\%) controls were had low knowledge and $90(94.7 \%)$ cases were highly knowledgeable (Figure 2).

\section{Determinants Associated with Overweight of the Primary School Children}

In bivariate analysis; occupation of father, occupation of mother, fruit consumption per week, vegetable consumption 
Table 2 Socio-Demographic Characteristics of Parents Among Primary School Children in Arba Minch Town, Southern Ethiopia, 202I

\begin{tabular}{|c|c|c|c|c|c|}
\hline \multirow[t]{2}{*}{ Variable $(n=285)$} & \multirow[t]{2}{*}{ Category } & \multicolumn{2}{|c|}{ Controls $(n=190)$} & \multicolumn{2}{|c|}{ Cases $(n=95)$} \\
\hline & & Frequency & Percent & Frequency & Percent \\
\hline \multirow[t]{4}{*}{ Religion of parents } & Orthodox & 88 & 46.3 & $4 \mid$ & 43.2 \\
\hline & Protestant & 75 & 39.5 & 32 & 33.7 \\
\hline & Muslim & 22 & 11.6 & 15 & 15.8 \\
\hline & Catholic & 5 & 2.6 & 7 & 7.4 \\
\hline \multirow[t]{4}{*}{ Ethnicity } & Gamo & 114 & 60.0 & 51 & 53.7 \\
\hline & Zayse & 31 & 16.3 & 27 & 28.4 \\
\hline & Gidicho & 29 & 15.3 & 12 & 12.6 \\
\hline & Others & 16 & 8.4 & 5 & 5.3 \\
\hline \multirow[t]{3}{*}{ Educational level of fathers } & Grade I-8 & 42 & 22.1 & 9 & 9.5 \\
\hline & Grade 9-12 & 139 & 73.2 & 39 & $4 I .1$ \\
\hline & >grade 12 & 9 & 4.7 & 47 & 49.5 \\
\hline \multirow[t]{4}{*}{ Educational level of mothers } & No formal education & 2 & I.I & 1 & I.I \\
\hline & Grade I-8 & 64 & 33.7 & 19 & 20.0 \\
\hline & Grade 9-12 & 117 & 61.6 & 56 & 58.9 \\
\hline & $>$ grade 12 & 7 & 3.7 & 19 & 20.0 \\
\hline \multirow[t]{4}{*}{ Occupation of father } & Government employee & 75 & 39.5 & 13 & 13.7 \\
\hline & Private business & 21 & 11.1 & 52 & 54.7 \\
\hline & Daily laborer & 4 & 2.1 & 0 & 0 \\
\hline & Merchant & 90 & 47.4 & 30 & 31.6 \\
\hline \multirow[t]{4}{*}{ Occupation of mother } & House wife & 8 & 4.2 & 3 & 3.2 \\
\hline & Government employee & 50 & 26.3 & 15 & 15.8 \\
\hline & Private business & 43 & 22.6 & 36 & 37.9 \\
\hline & Merchant & 89 & 46.8 & 41 & 43.2 \\
\hline \multirow[t]{2}{*}{ Number of people live in the house } & $<5$ & 24 & 12.6 & 30 & 31.6 \\
\hline & $>5$ & 166 & 87.4 & 65 & 66.4 \\
\hline
\end{tabular}

Note: Others: Gofa, Wolaita and Amhara.

Table 3 Socio-Demographic Characteristics of Study Participants Among Primary School Children in Arba Minch, Southern Ethiopia, 2021

\begin{tabular}{|c|c|c|c|c|c|}
\hline \multirow[t]{2}{*}{ Variable $(n=285)$} & \multirow[t]{2}{*}{ Category } & \multicolumn{2}{|c|}{ Controls $(n=190)$} & \multicolumn{2}{|c|}{ Cases $(n=95)$} \\
\hline & & Frequency & Percent & Frequency & Percent \\
\hline \multirow[t]{2}{*}{ Sex of child } & Male & 75 & 39.5 & 69 & 72.6 \\
\hline & Female & 115 & 60.5 & 26 & 27.4 \\
\hline \multirow[t]{5}{*}{ Age of child } & II & 37 & 19.5 & 19 & 20.0 \\
\hline & 12 & 30 & 15.8 & 22 & 23.2 \\
\hline & 13 & 37 & 19.5 & 22 & 23.2 \\
\hline & 14 & 38 & 20.0 & 19 & 20.0 \\
\hline & 15 & 48 & 25.3 & 13 & 13.7 \\
\hline \multirow[t]{2}{*}{ Type of school } & Government & 106 & 55.8 & 53 & 55.8 \\
\hline & Private & 84 & 44.2 & 42 & 44.2 \\
\hline \multirow[t]{4}{*}{ Grade level } & 5 th & 60 & 31.6 & 28 & 29.5 \\
\hline & 6th & 48 & 25.3 & 42 & 44.2 \\
\hline & 7th & 45 & 23.7 & 15 & 15.8 \\
\hline & 8th & 37 & 19.5 & 10 & 10.5 \\
\hline
\end{tabular}


Table 4 Eating Habits and Food Preferences of Primary School Children in Arba Minch Town, Southern Ethiopia, 202I

\begin{tabular}{|c|c|c|c|c|c|}
\hline \multirow[t]{2}{*}{ Variable $(n=285)$} & \multirow[t]{2}{*}{ Category } & \multicolumn{2}{|c|}{ Controls $(n=190)$} & \multicolumn{2}{|c|}{ Cases $(n=95)$} \\
\hline & & Frequency & Percent & Frequency & Percent \\
\hline \multirow{2}{*}{$\begin{array}{l}\text { Fruit consumption per week (mango, avocado, } \\
\text { orange, ...) }\end{array}$} & $\leq 2$ days & 34 & 17.9 & 46 & 48.4 \\
\hline & $>2$ days & 156 & 82.1 & 49 & 51.6 \\
\hline \multirow{2}{*}{$\begin{array}{l}\text { Vegetable consumption per week (potato, } \\
\text { carrot, ...) }\end{array}$} & $\leq 2$ days & 50 & 26.3 & 77 & 81.1 \\
\hline & $>2$ days & 140 & 73.7 & 18 & 18.9 \\
\hline \multirow{2}{*}{$\begin{array}{l}\text { Cereal consumption per week (maize, barely, } \\
\text { wheat, ...) }\end{array}$} & $\leq 2$ days & 69 & 36.3 & 64 & 67.4 \\
\hline & $>2$ days & 121 & 63.7 & 31 & 32.6 \\
\hline \multirow[t]{2}{*}{ Meat consumption per week } & $\leq 2$ days & 83 & 43.7 & 15 & 15.8 \\
\hline & $>2$ days & 107 & 56.3 & 80 & 84.2 \\
\hline \multirow{2}{*}{ Egg, pea, bean, ... consumption per week } & $\leq 2$ days & 106 & 55.8 & 41 & 43.2 \\
\hline & $>2$ days & 84 & 44.2 & 54 & 56.8 \\
\hline \multirow[t]{2}{*}{ Milk consumption per week } & $\leq 2$ days & 75 & 39.5 & 14 & 14.7 \\
\hline & $>2$ days & 115 & 60.5 & 81 & 85.3 \\
\hline \multirow[t]{2}{*}{ Frequency of eating per day } & $\leq 4$ times & 173 & 91.4 & 7 & 7.4 \\
\hline & $>4$ times & 17 & 8.9 & 88 & 92.6 \\
\hline \multirow[t]{4}{*}{ Food addition to regular meal } & Cake & 29 & 15.3 & 36 & 37.9 \\
\hline & Biscuit & 58 & 30.5 & 33 & 34.7 \\
\hline & Ice cream & 69 & 36.3 & 21 & 22.1 \\
\hline & Chocolate & 34 & 17.9 & 5 & 5.3 \\
\hline \multirow[t]{3}{*}{ Servings of soft drink per day } & 1 & 170 & 89.5 & 38 & 40.0 \\
\hline & 2 & 12 & 6.3 & 54 & 56.8 \\
\hline & 3 & 8 & 4.2 & 3 & 3.2 \\
\hline \multirow[t]{3}{*}{ Way of getting lunch } & Home & 147 & 77.4 & 60 & 63.2 \\
\hline & School cafeteria & 39 & 20.5 & 25 & 26.3 \\
\hline & $\begin{array}{l}\text { Nearby food } \\
\text { service }\end{array}$ & 4 & 2.1 & 10 & 10.5 \\
\hline \multirow[t]{2}{*}{ Eat food while watching TV } & Yes & 134 & 70.5 & 57 & 60.0 \\
\hline & No & 56 & 29.5 & 38 & 40.0 \\
\hline \multirow[t]{2}{*}{ Eat food while reading } & Yes & 38 & 20.0 & 10 & 10.5 \\
\hline & No & 152 & 80.0 & 85 & 89.5 \\
\hline \multirow[t]{2}{*}{ Habit of missing meal schedule } & Yes & 80 & 42.1 & 8 & 8.4 \\
\hline & No & 110 & 57.9 & 87 & 91.4 \\
\hline \multirow[t]{2}{*}{ Take anti-psychiatric drug } & Yes & 6 & 3.2 & 2 & 2.1 \\
\hline & No & 184 & 96.8 & 93 & 97.9 \\
\hline
\end{tabular}

per week, cereals consumption per week, meat consumption per week, milk consumption per week, eggs, peas, beans consumption per week and time spent sitting were associated. Whereas, in multivariate binary logistic regression analysis, occupation of father [AOR: 19.82, 95\% CI: 6.21 , 63.25], fruit consumption per week [AOR: $0.16,95 \% \mathrm{CI}: 0.06$,
0.42], vegetables consumption per week [AOR: $0.07,95 \% \mathrm{CI}$ : $0.03,0.19$ ], cereals consumption per week [AOR: $0.33,95 \%$ CI: $0.13,0.84$ ], meat consumption per week [AOR: $4.75,95 \%$ CI: 1.61, 14.03], milk consumption per week [AOR: 5.02, 95\% CI: 1.80, 13.98] and time spent sitting [AOR: 11.89, 95\% CI: 4.13, 34.28] were associated (Table 7). 
Table 5 Physical Activities of Primary School Children in Arba Minch Town, Southern Ethiopia, 202I

\begin{tabular}{|c|c|c|c|c|c|}
\hline \multirow[t]{2}{*}{ Variable $(n=285)$} & \multirow[t]{2}{*}{ Category } & \multicolumn{2}{|c|}{ Controls $(n=190)$} & \multicolumn{2}{|c|}{ Cases $(n=95)$} \\
\hline & & Frequency & Percent & Frequency & Percent \\
\hline \multirow[t]{2}{*}{ Engage in work beside education } & Yes & 46 & 24.2 & 32 & 33.7 \\
\hline & No & 144 & 75.8 & 63 & 66.3 \\
\hline \multirow[t]{2}{*}{ Work involve vigorous intensity activity at least for 10 minutes $(n=78)$} & Yes & 39 & 84.8 & 12 & 37.5 \\
\hline & No & 7 & 15.2 & 20 & 62.5 \\
\hline \multirow[t]{2}{*}{ Days vigorous intensity activity at least 10 minutes per week $(n=5 \mathrm{I})$} & $\leq 2$ days & 22 & 52.4 & 10 & 83.3 \\
\hline & $>2$ days & 20 & 47.6 & 2 & 16.7 \\
\hline \multirow[t]{2}{*}{ Time of vigorous intensity activity at least 10 minutes per day $(n=5 \mathrm{I})$} & $<60$ minutes & 35 & 89.7 & 11 & 91.7 \\
\hline & $>60$ minutes & 4 & 10.3 & I & 8.3 \\
\hline \multirow[t]{3}{*}{ Days of walking or riding bicycle for at least 10 minutes per week } & $\leq 2$ days & 3 & 1.6 & 45 & 47.4 \\
\hline & $3-4$ days & 6 & 3.2 & 37 & 38.9 \\
\hline & $\geq 5$ days & 181 & 95.3 & 13 & 13.7 \\
\hline \multirow[t]{3}{*}{ Time of walking or riding bicycle for at least 10 minutes per day } & $\leq 30$ minutes & 163 & 85.8 & 86 & 90.5 \\
\hline & $31-60$ minutes & 25 & 13.2 & 8 & 8.4 \\
\hline & $>60$ minutes & 2 & I.I & I & I.I \\
\hline \multirow[t]{2}{*}{ Do vigorous intensity sport for at least 10 minutes per day } & Yes & 8 & 4.2 & 3 & 3.2 \\
\hline & No & 182 & 95.8 & 92 & 96.8 \\
\hline
\end{tabular}

Table 6 Sedentary Behavior of Primary School Children in Arba Minch Town, Southern Ethiopia, 202I

\begin{tabular}{|c|c|c|c|c|c|}
\hline \multirow[t]{2}{*}{ Variable $(n=285)$} & \multirow[t]{2}{*}{ Category } & \multicolumn{2}{|c|}{ Controls $(n=190)$} & \multicolumn{2}{|c|}{ Cases $(n=95)$} \\
\hline & & Frequency & Percent & Frequency & Percent \\
\hline \multirow[t]{4}{*}{ Way of spending free time } & Reading books & 21 & II.I & 4 & 4.2 \\
\hline & Watching TV or Video & 37 & 19.5 & 73 & 76.8 \\
\hline & Playing computer/mobile game & 54 & 28.4 & 17 & 17.9 \\
\hline & Helping family & 78 & 41.1 & 1 & 1.1 \\
\hline \multirow[t]{2}{*}{ Time spend on sitting } & $\leq 6$ hours & 159 & 83.7 & 47 & 49.5 \\
\hline & $>6$ hours & 31 & 16.3 & 48 & 50.5 \\
\hline \multirow[t]{2}{*}{ Sleeping habit in the afternoon } & Yes & 12 & 6.3 & 68 & 71.6 \\
\hline & No & 178 & 93.7 & 27 & 28.4 \\
\hline \multirow[t]{2}{*}{ Average sleeping duration of sleeping per day $(n=80)$} & $34-45$ minutes & 12 & 100.0 & 42 & 61.8 \\
\hline & $>45$ minutes & 0 & 0.0 & 26 & 38.2 \\
\hline \multirow{2}{*}{$\begin{array}{l}\text { Familial chronic diseases (DM, hypertension, renal, heart, } \\
\text { arthritis) }\end{array}$} & Yes & 11 & 5.8 & 11 & 11.6 \\
\hline & No & 179 & 94.2 & 84 & 88.4 \\
\hline
\end{tabular}

Abbreviations: TV, television; DM, diabetes mellitus.

\section{Discussion}

In this study, after controlling for other confounding factors, occupation of father, fruit consumption per week, vegetables consumption per week, cereals consumption per week, meat consumption per week, milk consumption per week and time spent sitting were found to be determinant factors for risk of childhood overweight.
The findings of this study indicated that the odds of overweight increased about 19.8 times more comparing primary school children whose fathers worked in private business with those who were merchants [AOR: 19.82, 95\% CI: 6.21, 63.25]. This was supported in other studies in that fraternal overweight has some contribution to the child. ${ }^{24,25}$ This might be because fathers who work in their 


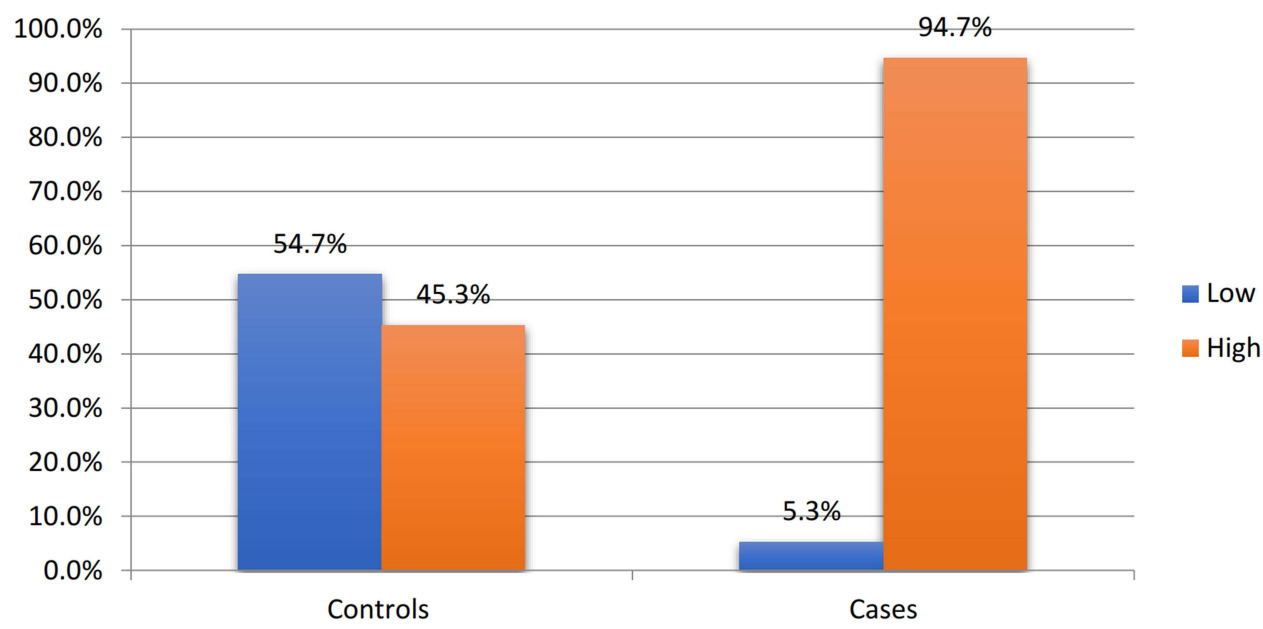

Figure 2 Nutritional knowledge of primary school children in Arba Minch town, Southern Ethiopia, 202I.

own private business have better socio-economic status and have access to fat-rich foods and a sedentary lifestyle. $^{1,2,24}$ On the other hand, in low-income countries such as Ethiopia, patterns of expenditure on high-energy foods and childhood overweight have been considered as signs of better socio-economic status and healthiness of

Table 7 Bivariable and Multivariable Logistic Regression of Determinants of Overweight Among Primary School Children in Arba Minch Town, Southern Ethiopia, 202I

\begin{tabular}{|c|c|c|c|c|c|c|}
\hline \multirow[t]{2}{*}{ Variables $(n=285)$} & \multirow[t]{2}{*}{ Category } & \multicolumn{2}{|c|}{ Overweight } & \multirow[t]{2}{*}{ COR $(95 \% \mathrm{Cl})$} & \multirow[t]{2}{*}{ AOR (95\% Cl) } & \multirow{2}{*}{$\begin{array}{l}\text { P-value of } \\
\text { AOR }\end{array}$} \\
\hline & & $\begin{array}{l}\text { Case } \\
(n=95)\end{array}$ & $\begin{array}{l}\text { Control } \\
(\mathrm{n}=190)\end{array}$ & & & \\
\hline \multirow[t]{4}{*}{ Occupation of father } & Government employee & $13(4.6)$ & $75(26.3)$ & $0.52(0.25,1.07)$ & $0.46(0.13,1.63)$ & 0.225 \\
\hline & Private business & $52(\mid 8.2)$ & $21(7.4)$ & $7.43(3.86,14.28)$ & 19.82(6.21, 63.25) & $0.000 * * *$ \\
\hline & Daily laborer & & $4(1.4)$ & 0.000 & 0.00 & 0.999 \\
\hline & Merchant & $30(10.5)$ & $90(31.6)$ & I & 1 & \\
\hline \multirow[t]{4}{*}{ Occupation of mother } & Housewife & $3(1.1)$ & $8(2.8)$ & $0.08(0.21,3.23)$ & $0.86(0.03,28.38)$ & 0.931 \\
\hline & Government employee & $15(5.3)$ & $50(17.5)$ & $0.65(0.33,1.29)$ & $2.18(0.57,8.38)$ & 0.255 \\
\hline & Private business & $36(12.6)$ & $43(15.1)$ & $1.82(1.02,3.24)$ & $1.83(0.69,4.90)$ & 0.226 \\
\hline & Merchant & $4 I(14.4)$ & $89(31.2)$ & 1 & 1 & \\
\hline \multirow[t]{2}{*}{ Fruit consumption per week } & $\leq 2$ days & $34(11.9)$ & $46(16.1)$ & 1 & 1 & \\
\hline & $>2$ days & $156(54.7)$ & $49(17.2)$ & $0.23(0.13,0.40)$ & $0.16(0.06,0.42)$ & $0.000 * * *$ \\
\hline \multirow[t]{2}{*}{ Vegetable consumption per week } & $\leq 2$ days & $50(17.5)$ & $77(27.0)$ & 1 & 1 & \\
\hline & $>2$ days & $140(49.1)$ & $18(6.3)$ & $0.08(0.05,0.15)$ & $0.07(0.03,0.19)$ & $0.000 * * *$ \\
\hline \multirow[t]{2}{*}{ Cereal consumption per week } & $\leq 2$ days & $69(24.2)$ & $64(22.5)$ & 1 & I & \\
\hline & $>2$ days & $|2|(42.5)$ & $31(10.9)$ & $0.27(0.16,0.46)$ & $0.33(0.13,0.84)$ & $0.020 *$ \\
\hline \multirow[t]{2}{*}{ Meat consumption per week } & $\leq 2$ days & $83(29.1)$ & $15(5.3)$ & 1 & 1 & \\
\hline & $>2$ days & $107(37.5)$ & $80(28.1)$ & $4.14(2.22,7.70)$ & $4.75(1.61,14.03)$ & $0.005^{* *}$ \\
\hline \multirow[t]{2}{*}{ Milk consumption per week } & $\leq 2$ days & $75(26.3)$ & $14(4.9)$ & 1 & I & \\
\hline & $>2$ days & $115(40.4)$ & $8 I(28.4)$ & $3.77(1.99,7.14)$ & $5.02(1.80,13.98)$ & $0.002 * *$ \\
\hline \multirow{2}{*}{$\begin{array}{l}\text { Egg, pea, bean, consumption per } \\
\text { week }\end{array}$} & $\leq 2$ days & $106(37.2)$ & $4 I(14.4)$ & 1 & I & \\
\hline & $>2$ days & $84(29.5)$ & $54(18.9)$ & $1.66(1.01,2.73)$ & $1.26(0.49,3.23)$ & 0.626 \\
\hline \multirow[t]{2}{*}{ Time spend on sitting } & $\leq 6$ hours & $159(55.8)$ & $47(16.5)$ & 1 & 1 & \\
\hline & $>6$ hours & $31(10.9)$ & $48(16.8)$ & $5.24(3.00,9.14)$ & II.89(4.13, 34.28) & $0.000 * * *$ \\
\hline
\end{tabular}

Notes: *Statistically associated at $p<0.05$, * Statistically associated at $p \leq 0.0$ I, ***Statistically associated at $p \leq 0.00$ I, "I" reference group. Abbreviations: COR, crude odds ratio; AOR, adjusted odds ratio. 
parent. ${ }^{24}$ Parents having better income mostly consume high fat and sugar content foods that lead to being overweight. $^{1,25}$ They also mostly have their own transportation vehicles, thus minimizing the chance of walking in day to day activities. As result, children of the parents that have better income consume fat-rich meals and go to school by the family's transportation, and these conditions contribute to childhood overweight.

In bivariable analysis, maternal occupation was significantly associated with overweight of primary school children. The odds of overweight increased 1.8 times more comparing primary school children whose mothers' occupation was private business to primary school children whose mothers' occupation was merchant. This might be due to better monthly income. Monthly income level was a determinant of overweight for primary school children in other studies. $^{26,27}$ But, when confounding factors were adjusted, the association was not statistically significant.

In this study, the odds of overweight decreased by about $84 \%$ when comparing primary school children whose consumption of fruit per week was greater than 2 days with those who consume fruit less than or equal to 2 days per week [AOR: $0.16,95 \% \mathrm{CI}: 0.06,0.42$ ]. This might be due to fruits containing roughage and fiber that are mostly removed from the body. Consuming high roughage and fiber foods frequently in dietary habit minimizes the chance of fat accumulation in the body, and lead to normal height and weight balance of the children.

The odds of overweight decreased by about $93 \%$ when comparing primary school children whose consumption of vegetable per week was greater than 2 days to those who consume vegetable less than or equal to 2 days per week [AOR: 0.07, 95\% CI: 0.03, 0.19]. It was supported by a study conducted in Dire Dawa. ${ }^{18}$ This could be related with the nature of the food in that vegetables contain lower amounts of fat. As a result, consuming these foods for more than two days per week prevents children becoming overweight.

The odds of overweight decreased by about $67 \%$ when comparing primary school children whose consumption of cereals (barley, wheat, sorghum, rice) per week was greater than 2 days to those who consume cereals less than or equal to 2 days per week [AOR: 0.33 , 95\% CI: $0.13,0.84]$. This could be because cereals contain carbohydrate, and protein contents. From this, carbohydrates contribute to fat accumulation of weight, and proteins contribute to body growth of the children. As a result, consumption of cereals may balance the normal growth of the children. As the childhood is an age of growth, these foods initiate normal body balance.

The odds of overweight increased about 4.8 times more comparing primary school children whose meat consumption per week was greater than 2 days with those who consume meat less than or equal to 2 days per week [AOR: 4.75, 95\% CI: 1.61, 14.03]. This result was supported by other reports, which indicated that consumption of fat, and sugar-rich foods contribute to childhood overweight. $^{1,2}$ The reason for this might be that meat is high in calories, and a fat-rich food resulting in a positive energy balance for children.

The odds of overweight increased about 5 times more comparing primary school children whose milk consumption per week was greater than 2 days with those who consume milk less than or equal to 2 days per week [AOR: 5.02, 95\% CI: 1.80, 13.98]. This could be because milk contains many nutrients that help in body growth of children. The other reason might be that milk has the potential to enhance appetite when consumed with other foods containing carbohydrates, which leads to eating more than the usual amount at the time.

In bivariable analysis, the odds of overweight increased by about 1.6 times comparing primary school children whose eggs, peas, or beans consumption per week was greater than 2 days to those who consumed eggs, peas, or beans less than or equal to 2 days per week. But, when confounding factors were adjusted, the association was not statistically significant.

The odds of overweight increased by about 11.9 times comparing primary school children whose time spent sitting per day was greater than 6 hours to those whose time spent sitting per day was less than or equal to 6 hours [AOR: 11.89, 95\% CI: 4.13, 34.28]. As was stated in other studies, physical inactivity is an important determinant of overweight among children. ${ }^{5,28}$ This could be because when the child sits in one place, the fat content in the body does not burn off, and this leads to more risk of overweight, and physical immobility induces overweight.

\section{Conclusion}

In general, primary school children with fathers who work in private business, children who consume fruit, vegetables, cereals, meat, and milk on more than 2 days per week, and children whose time spent sitting was greater than 6 hours per day were determinant factors for overweight in primary school children in Arba Minch town. 


\section{Recommendation}

To minimize the risk of overweight, primary school children or parents should:

- It is better to include fruit, vegetables, and cereals in their dietary habit for 2 or more days per week.

- Should decrease consuming meat, and milk at most 2 days per week.

- Should minimize sitting for less than 6 hours per day including school learning time.

\section{Abbreviations}

AM, Arba Minch; AOR, Adjusted Odds Ratio; BMI, Body Mass Index; BT, Birhan Tena; CI, Confidence Interval; COR, Crude Odds Ratio; DM, Diabetes Mellitus; HL, Hibiret Lelimat; SPSS, Statistically Package of Social Science; TV, Television; WHO, World Health Organization.

\section{Data Sharing Statement}

The datasets used and/or analyzed during the current study are available from the corresponding author on reasonable request.

\section{Ethical Clearance}

Research ethical review committee of Paramed College approved this research proposal. Then a support letter was obtained from Arba Minch town education office, and was sent to each sub-city administrative. Finally, each sub-city administrative sent a support letter for each selected primary school. After getting permission from each school, the participants' parents were informed the purpose was only for this research, by sending a written consent letter on students. Based on their parents' acceptance, a written asset was taken from each participant student. Coding was used to eliminate names and other personal identification of respondents to ensure anonymity, privacy, and confidentiality. Thoroughly, our research passed the required principles of Declaration of Helsinki General Assembly, Seoul, Korea, and October 2008.

\section{Acknowledgments}

We would like to thank the supervisors for their critical supervision, data collectors for collecting accurate data, and study participants for their willingness of participation, kind provision of necessary information, and sacrifice of their valuable time spent during interviews.

\section{Author Contributions}

Both authors made a significant contribution to the work reported, whether that is in the conception, study design, execution, acquisition of data, analysis, and interpretation, or in all areas; took part in drafting, revising and critically reviewing the article; gave final approval of the version to be published; have agreed on the journal to which the article has been submitted; and agreed to be accountable for all aspects of the work.

\section{Funding}

The authors did not get specified funding for this study.

\section{Disclosure}

Both authors declare that they have no conflict of interests for this work.

\section{References}

1. United Nations Children's Fund (UNICEF). Prevention of Overweight and Obesity in Children and Adolescents: UNICEF Programming Guidance. New York: United Nations Children's Fund (UNICEF); 2019.

2. WHO. Report of the Commission on Ending Childhood Obesity. Geneva: WHO; 2016.

3. WHO. World health organization: obesity and overweight fact sheet $\mathrm{N}^{\circ} 311$ [Internet]. 2015. Available from: https://apps.who.int/infobase/ Accessed November 18, 2015.

4. IFPRI. 2016 Global Nutrition Report. Washington, D.C.: IFPRI; 2016:10-12.

5. Akseer N, Al Gashm S, Mehta S, Mokdad A, Bhutta ZA. Global and regional trends in the nutritional status of young people: a critical and neglected age group. Ann NY Acad Sci. 2017;1393(1):3-20. doi:10.1111/nyas. 13336

6. UNICEF annual report 2016, Ethiopia; 2018. Available from: www. unicef.org/about/annualreport/files/Ethiopia_2016_COAR.pdf. Accessed August 18, 2018.

7. Keats S, Wiggins S. Future diets Future diets; 2014.

8. World Health Organization. Consideration of the Evidence on Childhood Obesity for the Commission on Ending Childhood Obesity Report of the Ad Hoc Working Group on Science and Evidence for Ending Childhood Obesity. Geneva, Switzerland: World Health Organization; 2016.

9. Ng M, Fleming T, Robinson M, et al. Global, regional, and national prevalence of overweight and obesity in children and adults during 1980-2013: a systematic analysis for the global burden of disease study, 2013. Lancet. 2014;384:766-781. doi:10.1016/S01406736(14)60460-8

10. Bereket AH, Beyero M, Fikadu AR, Bosha T. Risk factors for overweight and obesity in private high school adolescents in Hawassa City. Southern Ethiopia: a case-control study. Food Public Health. 2017;7(2):29-34.

11. Amidu N, Owiredu WK, Saaka M, Quaye L, Wanwan PD, Kumibea FMZ. Determinants of childhood obesity among basic school children aged 6-12 years in Tamale Metropolis. $J$ Med Biomed Sci. 2013;2(3):26-34.

12. Ali MS, Worku C, Chalachew K, Wubneh A. Over nutrition and associated factors a comparative cross sectional study among private and governmental primary school children in Gondar town; 2020. 
13. FMOH. Federal Democratic Republic of Ethiopia national nutrition program 2016-2020; 2016.

14. Central Statistical Agency (CSA) [Ethiopia] and ICF. Ethiopia Demographic and Health Survey 2016. Addis Ababa, Ethiopia, and Rockville, Maryland, USA: CSA and ICF; 2016:187-190.

15. Adinew N, Tilahun B. Determinants of overweight among government employees in Gibe District, Hadiya Zone, Southern Ethiopia: a case control study. J Health Med Nurs. 2019;60:26-27.

16. World Health Organization. WHO Reference; BMI-For-Age GIRLS Thinness Severe Thinness NACS USER'S GUIDE MODULE 2 Nutrition Assessment and Classification. World Health Organization; 2007:28.

17. World Health Organization. WHO Reference; BMI-For-Age BOYS Thinness Severe Thinness NACS USER'S GUIDE MODULE 2 Nutrition Assessment and Classification. World Health Organization; 2007:27.

18. Desalew A, Mandesh A, Semahegn A. Childhood overweight, obesity and associated factors among primary school children in Dire Dawa, Eastern Ethiopia; 2016.

19. Gebremichael B, Chere A. Prevalence of childhood overweight and obesity and its determinant factors among elementary school children in Addis Ababa, Ethiopia: a cross sectional study. J Nutr Disord Ther. 2015;5:168

20. WHO. WHO Health Statistics Monitoring Health for SDGs. WHO; 2018.

21. Nirmala A, Kanniammal C, Venkataraman P, Arulappan J. Predisposing factors associated with obesity among adolescents-a case control study. Biomed Res. 2018;29(18):3497-3501.
22. FAO. Guidelines for assessing nutrition-related knowledge, attitudes and practices manual; 2014.

23. WHO. Global Physical Activity Questionnaire (GPAQ) WHO STEPwise Approach to NCD Risk Factor Surveillance. WHO; 2007:1-3

24. Mitanchez D, Chavatte-Palmer P. Review shows that maternal obesity induces serious adverse neonatal effects and is associated with childhood obesity in their offspring. Acta Paediatr. 2018;107 (7):1156-1165. doi:10.1111/apa.14269

25. Martinez A. Epigenetics within the double burden of malnutrition. Presentation to the IAEA/UNICEF/WHO symposium on the double burden of malnutrition; 2018. Available from: https://humanhealth. iaea.org/HHW/Nutrition/Symposium2018/presentations/7.2. Martinez.pdf. Accessed June 16, 2021.

26. Badawi NE, Barakat AA, Awad S, Sherbini E. Prevalence of overweight and obesity in primary school children in Port Said city. Egypt Paediatr Assoc. 2013;61(1):31-36. doi:10.1016/j.epag.2013.04.007

27. Mocanu V. Prevalence of overweight and obesity in urban elementary school children in Northeastern Romania: its relationship with socioeconomic status and associated dietary and lifestyle factors. Biomed Res Int. 2013;2013(537451):7. doi:10.1155/2013/537451

28. Guthold R, Stevens GA, Riley LM, Bull FC. Worldwide trends in insufficient physical activity from 2001 to 2006: a pooled analysis of 358 population-based surveys with 1.9 million participants. Lancet Glob Health. 2018;6(10):1077-1086. doi:10.1016/S2214-109X(18) 30357-7
Adolescent Health, Medicine and Therapeutics

\section{Publish your work in this journal}

Adolescent Health, Medicine and Therapeutics is an international, peer-reviewed, open access journal focusing on health, pathology, and treatment issues specific to the adolescent age group. All aspects of health maintenance, preventative measures and disease treatment interventions are addressed within the journal and practitioners from

\section{Dovepress}

all disciplines are invited to submit their work as well as healthcare researchers and patient support groups. The manuscript management system is completely online and includes a very quick and fair peerreview system. Visit http://www.dovepress.com/testimonials.php to read real quotes from published authors. 